„Bohemistyka” 2020, nr 2, ISSN 1642-9893

\title{
Różnice w czeskich i polskich przekładach na przykładzie biblijnego reprezentanta awifauny - żurawia
}

Keywords: interpretation, picture and biblical symbolism, translation, language's equivalence and synonymous lexical units.

Słowa kluczowe: przekład, translacja i tłumaczenie, obraz i symbolika biblijna, ekwiwalencja językowa i synonimiczna bliskoznaczność leksykalna.

\section{Abstract}

In this article, based on sixteen various biblical translations (eight Czech and eight Polish) exclusively referring to two Old Testament verses, the author tries to present the translational differences in avifauna paying special attention to its representativea crane. The author focuses on various aspects of translational differences both interalinguistic and interlinguistic as well as on the established image and the deep-rooted symbolism of the described representative of the semantic category of fowl, which is the lexically basic crane.

W niniejszym artykule autor na podstawie szesnastu zaprezentowanych różnorodnych wersji przekładów biblijnych (ośmiu czeskich i ośmiu polskich) dotyczacych wyłącznie dwóch starotestamentowych wersetów (Iz 38,14 i Jr 8,7) podejmuje próbę pokazania różnic translacyjnych z zakresu awifauny, zwracając szczególną uwagę na jej przedstawiciela żurawia. Autor zwraca uwagę na różnorodne aspekty zarówno wewnątrzjęzykowe, jak i na międzyjęzykowe różnice translacyjne oraz na utrwalony obraz i zakorzenioną symbolikę opisywanego reprezentanta kategorii pojęciowej ptactwa, jakim jest bazowy leksem żuraw.

ŻURAW (łac. Grus grus) czes. JEŘÁB popelavý 'duży ptak bagienny, z długimi nogami, długą, smukłą szyją; żyje w Eurazji, w Polsce rzadki' (Dunaj 2001, s. 902-903); czes. jeřáb 'velký pták s vysokýma nohama žijící na bažinách' (Filipec, Daneš, Mejstř́k 2005, s. 121). Ptak ten należy do rodziny Gruidae, czes. čeled' jeřábovití. Najbar- 
dziej znani przedstawiciele z tej rodziny to: jeřáb popelavý (Grus grus) i jeřáb panenský (Grus/Anthropoides vigro) - żuraw stepowy. Żuraw jest jednym z największych ptaków żyjących w Ziemi Świętej. Jego skrzydła mają rozpiętość $2,1 \mathrm{~m}$, a w pozycji stojącej ptak ten osiąga wysokość 1,2 m. Jest to ptak brodzący, który żywi się żabami, rybami i owadami. Z tego też powodu - jak podkreśla Słownik tła Biblii - chociaż przedstawiciel ten reprezentujący awifaunę (por. hebr. 'āgūr [h-5693]) nie znajduje się bezpośrednio w wykazie ptaków zakazanych do konsumpcji, to jednak Żydzi uważali żurawia za zwierzę nieczyste (por. Packer, Tenney 2007, s. 182). Żurawie są najpiękniejsze w porannej mgle, ponieważ wyglądają wtedy jak przysłowiowe „ptasie katedry“ (Kruszona 2008, s. 79).

Zgodnie z tendencją dotyczącą zaproponowania dokładnej analizy językoznawczej i przyjętej strategii, jaką pragnę przedstawić (patrz 21 punktów w końcowej części artykułu), żaden $\mathrm{z}$ autorów powstających dziś prac translatologicznych (por. Tabakowska 2001, 2008, 2009; Brzozowski 2011; Lipiński 2004, 2006; Stěpanova 2009; Bednarczyk 2008; Hejwowski 2006; Majkiewicz 2008; Grygová 2010; Zehnalová 2010; Baláková 2007; Kufnerová 2009) nie może pozostać obojętny wobec kluczowego dla przekładu problemu, jakim jest ekwiwalencja.

W przeprowadzonej przeze mnie analizie językowej, dotyczącej szesnastu przebadanych przekładów Pisma Świętego (ośmiu czeskich i ośmiu polskich) ${ }^{1}$, odnalazłem tylko dwa wersety biblijne (Iz 38,14 i Jr 8,7), w których pojawia się jeden z ważnych przedstawicieli awifauny, czyli bazowe wyrażenie żuraw (czes. jeřáb). W związku z tym

${ }^{1}$ Do analizy wykorzystałem dwa staroczeskie przekłady Pisma Świętego: BK (Bible kralická 1613), BO (Bible olomoucká 1417) i sześć współczesnych czeskich thumaczeń Biblii: ČEP (Český ekumenický překlad), ČSP (Český studijní překlad) B21 (Bible překlad 21. století), PNS (Překlad nového světa), JB (Jeruzalémská bible), SNC (Slovo na cestu). Z polskojęzycznych Biblii przebadałem dwie staropolskie: BG (Biblia Gdańska 1632) i BJW (Biblia Jakuba Wujka 1599) oraz sześć przekładów współczesnych: NBG (Nowa Biblia Gdańska), BT (Biblia Tysiąclecia), BWP (Biblia Warszawsko-Praska), BW (Biblia Warszawska), BP (Biblia Poznańska), PNŚ (Przekład Nowego Świata). zdecydowanie warto byłoby temu ptakowi poświęcić trochę uwagi, miejsca i czasu oraz spróbować dokładnie prześledzić, w jaki sposób zostały przetłumaczone te dwa wersety biblijne, uwzględniając szczególnie zastosowane i wykorzystane ptasie nazewnictwo, jakie znajduje się w tych dwóch fragmentach biblijnych.

Pierwszy przykład, w którym spotykamy się z wykorzystanym ekwiwalentem językowym w postaci przetłumaczonego leksemu żurawia (czes. jeřába) - jako jednego z przedstawicieli kategorii pojęciowej ptactwa - dotyczy Księgi Izajasza (Iz 38,14), zaliczanej do kanonu ksiąg prorockich Starego Testamentu. W 38 rozdziale księgi prorockiej, zwłaszcza w wersecie 14 odczuwalne jest nawiązanie do głosu ptaków, które zostały - jak zauważyłem na podstawie szczegółowej analizy - różnie przetłumaczone. Opisane zostało wołanie biblijnego króla Ezechiasza po uzdrowieniu z choroby, gdzie - jak możemy się domyślać - został wyrażony jednocześnie stan duchowy narodu wybranego. Głosy niektórych ptaków - traktowane w kategoriach pojęciowych ,wzór dla ludzi”, jak np. głos jerzyka, żurawia lub gotębia, brzmiały w uszach człowieka smutno (Ryken, Wilhoit, Longman 1998, s. 846), co również zostało odnotowane w czeskim komentarzu biblijnym:

[...] kde trpitel přirovnává své vzdechy k pištění rorejsů a jeřábů, a kvílivý hlas hrdliček či holubic připomíná sténání trpícího člověka před smrtí (Výklady IV 1998 , s. 141).

Natomiast czeskojęzyczny Biblický slovnik skupia się na fragmencie Iz 38,14: mluví o lkavém, úzkostlivém pípání mlád'at (Novotný 1992, s. 830). Przedstawiany fragment - jak podkreśla Encyklopedia Biblijna - wspomina o hałaśliwości zaprezentowanych ptaków (Achtemeier 2004, s. 1402). Dobrze ten fakt został odzwierciedlony w pierwszym analizowanym przykładzie, spośroód przedstawionych poniżej wyekscerpowanych czeskich i polskich przekładów biblijnych (por. zwłaszcza wyrażenia pogrubione - profilujące żurawia - oraz podkreślone - eksponujące pozostałych przedstawicieli awifauny): 
(I) BK Jako řeřáb a vlaštovice pištěl jsem, lkal jsem jako holubice, oči mé zhưru pozdvižené byly. Pane, násilé trpím, ó prodliž mi života. (Proroctví Izaiáše proroka 38,14) - (tłum. BK 2009, s. 602).

BO Jako ptáče vlastovičie tak budu volati, mysliti budu jako holubicě. Zemdlile sta sě oči moji vzhlédajice nahoru. Hospodine, násilé trpím, otpověz za mè. (Izaiáš 38,14) - (tłum. BO 2009, s. 111).

ČEP Jako rorejs a jeřáb, tak sípám, kvilím jako holubice, zemdlely mé oči upirajicí se na výšinu. Panovniku, jsem v tísni, zasad' se o mne! (Izajáš 38,14) - (tłum. ČEP 2008, s. 719).

ČSP Jako rorejs nebo jeřáb, tak sípu, lkám jako holubice, mé oči zeslábly hleděním vzhưru: Panovníku, jsem utištěn, zastaň se mě! (Izajáš 38,14) (tłum. CSP 2009, s. 869).

B21 Kvilim jako drozd anebo rorejs, nařikám jako holubice, oči mi slábnou, jak vzhůru vyhližím, stůj při mně, Pane, jsem sevřen úzkostí! (Izajáš 38,14) (tłum. B21 2009, s. 916).

PNS Jako rorýs, bulbul, tak stále pípám; stále vrkám jako holubice. Mé oči ochable vzhližely $k$ výšině: ,Jehovo, jsem utlačován. Zastan̆ se mne. ' (Iz 38,14) - (http://www.jw.org/cs/publikace/bible-online)

JB Jako vlaštovka pípám, sténám jako holubice, mé oči slábnou, jak se divám vzhůru. Pane, jsem zmožen, přijd' mi na pomoc. (Izaiáš 38,14) - (thum. JB 2009, s. 1354).

SNC Nařikal jsem jako rorýs či jestřáb a sténal jako truchlící holubice. Stálejsem vzhližel knebi, až mi začal slábnout zrak. (Izajáš 38,14) - (tłum. SNC 2011, s. 822).

BG Jako źóraw i jaskótka szczebiotatem, stękatem jako gotębica; oczy moje ku górze podniesione byty, i rzektem: Panie! gwatt cierpie, przedtuz mi żywota. (Proroctwo Izajaszowe 38,14) - (thum. BG s. 574).

BJW Jak młode jaskótcze, tak będe szczebiotat a będę stękat jako gotębica. Zemdlaty oczy moje, pogladajac ku górze, Panie, gwalt cierpie, odpowiedz za mię! (Proroctwo Izajaszowe 38,14) - (thum. BJW 2000, s. 1527)

NBG Kwiliłem jak zawodzaca jaskótka, gruchałem jak gołebica; tęskno, ku górze zwracałem moje oczy, mówiac: WIEKUISTY, pokrzep mnie, weź mnie w opieke. (Iz 38,14) - (http://www.biblest.com.pl).

BT Jak piskle jaskótcze, tak kwile, wzdycham jak gołebica. Oczy me słabna patrzac ku górze. Panie, cierpię ucisk: Stań przy mnie! (Księga Izajasza $38,14)$ - (thum. BT 1989, s. 881).

BWP A ja jak jaskótka kwile i wzdycham jak gołebica. Oczy me wznosze ku górze i proszę, byś się mna zająt i otoczyt mnie swoja opieka. (Iz 38,14) - (thum. BWP 1997, s. 1465).
Jak piskle jaskółcze, tak świergotałem, gruchałem jak gołab. Moje oczy zmęczone, zwrócone ku górze: Panie! Mękę cierpię, ujmij się za mną! (Księga Izajasza 38,14) - (tłum. BW 2001, s. 784).

BP Kwile jak napadnięta jaskótka, jak gołab wydaję westchnienia. Trwożnie poglądaja me oczy ku górze. Jestem w udręce, o Panie! Przybądź mi z pomoca! (Księga Izajasza 38,14) - (tłum. BP 2012, s. 1074).

PNŚ Jak jerzyk, bilbil, tak kwile; grucham jak gołab. Moje oczy osłabłe spogladaja ku wysokości: 'Jehowo, jestem w udręce. Stań w mojej obronie'. (Księga Izajasza 38,14) - (tłum. PNŚ 1997, s. 933)

W powyższych wyekscerpowanych tłumaczeniach biblijnych, skupiając się przede wszystkim na przeprowadzanej analizie leksykaInej, dostrzegłem pewne nieścisłości oraz istotne różnice, związane z szeroko rozumianym procesem przekładoznawczym. Polegają one przede wszystkim na tym, że w badanym wersecie spotykamy się z odmienna ilościa przetłumaczonych ptaków. Raz mamy do czynienia $\mathrm{z}$ wyszczególnionymi dwoma ptakami (BO, JB, BJW, NBG, BT, BWP, BW i BP), a następnym razem z trze ma przed st a w i c i e la mi a w i fu an y (BK, ČEP, ČSP, B21, PNS, SNC, BG i PNŚ).

Zagłębiając się dokładniej w analizowany tekst biblijny, możemy dostrzec, że w tych tłumaczeniach, w których zostali wyszczególnieni tylko „dwaj” reprezentanci kategorii pojęciowej ptactwa, wymieniane są najczęściej następujące gatunki ptaków: czes. vlaštovka i holubice - pol. jaskółka i gołębica. W Biblii Jakuba Wujka (BJW) spotykamy się z niemal identyczną sytuacją, tylko mamy do czynienie za zmianą rodzaju gramatycznego (por. kognitywne uwarunkowania rodzaju żywotnego, opisane w pracy: Vondráček 2008). Zamiast jaskółki zostało wymienione młode jaskółczę, a w BT i BW zamiast wyrażenia młode jaskółczę zostało użyte piskle jaskółcze (por. różnice w p r o fi 1 o w a ni u i obrazow an i u - L angacker 1987, 2003; Lakoff, Johnson 1988, Taylor 2001, 2007 - czyli nadawaniu przedmiotowi określonego kształtu). W czeskojęzycznym przekładzie Biblii Ołomunieckiej (BO) spotykamy się z analogiczną sytuacją, por. ptáče vlastovičie. Wczytując się dokładnie w zaprezentowane teksty, możemy w powyższym analizowanym wersecie również dopatrzyć się zamiany rodzaju gramatycznego jeszcze innego ptaka. Dotyczy to trzech polskoję- 
zycznych przekładów (BW, BP i PNŚ), gdzie został wykorzystany kohiponim gołab (rodzaj męski), a w pozostałych trzynastu przywoływanych thumaczeniach - ośmiu czeskich i pięciu polskich (BK, BO, ČEP, ČSP, B21, PNS, JB, SNC, BG, BJW, NBG, BT i BWP) wszędzie mamy gotębicę (czes. holubici) - rodzaj żeński. Pragnę jednak podkreślić dosyć istotny fakt, że wspomniana zmiana rodzaju gramatycznego nie wpływa w najmniejszej mierze na symbolikę analizowanego ptaka, pochodzącego z rodziny Columbidae ${ }^{2}$.

Natomiast spośród szesnastu analizowanych przekładów (Iz 38,14) z żurawiem spotykamy się tylko w czterech przekładach biblijnych - trzech czeskich i jednym polskim (por. BK, ČEP, ČSP i BG). Jednak trzeba również zwrócić tu uwagę na istotną różnicę, dotycząca kolejności wymienianych ptasich ekwiwalentów językowych. W staroczeskim wydaniu Biblii Kralickiej (BK) i staropolskiej edycji Biblii Gdańskiej (BG) analizowany żuraw został wyprofilowany na pi e r w s zy m miejscu ${ }^{3}$, a we współczesnych dwóch thumaczeniach: Česky ekumenický překlad (ČEP) i Český studijni překlad (ČSP) został wymieniony na d ru g i m miejscu, spośród trzech nazw ptaków, znajdujących się w tym wersecie.

Jak już wspomniałem, w analizowanych czeskich i polskich thumaczeniach biblijnych pojawiają się w każdym analizowanym wersecie albo trzy albo dwie nazwy gatunków ptaków, które zostały przetłumaczone na różny sposób ${ }^{4}$, w konsekwencji czego pojawiło się w czeskich przekładach aż siedmiu przedstawicieli kategorii pojęciowej ptactwa: czes. jeřáb, vlaštovice, holubice, rorejs, drozd, bulbul i jestráb, a w polskich przekładach biblijnych tylko pięciu reprezentan-

${ }^{2}$ Problematykę zmiany rodzaju gramatycznego w przekładach biblijnych opisa Zdzisław Kempf w swoim artykule Golębica czy gołab? (Kempf 1984, s. 335-341).

${ }^{3}$ Na podstawie również innych przeprowadzonych analiz (por. Kossowska 1968, Kwilecka 2003, Kyas 1997) możemy stwierdzić, że Biblia Kralicka miała wpływ na ostateczny kształt thumaczenia staropolskiej protestanckiej Biblii Gdańskiej.

${ }^{4}$ Analizując nazwy ptaków zauważyłem, że niektóre nazwy przybierają postacie hipotetyczne, różniące się zastosowana ekwiwalencja leksykalna. Szczególnie ten proces różnorodnie stosowanego nazewnictwa pojawia się na kartach Biblii w Księ- tów: żuraw, jaskółka, gołębica, jerzyk i bilbil, zachowując również różną kolejność przytaczania poszczególnych przedstawicieli awifauny. Dla lepszego przybliżenia opisywanej problematyki należy stwierdzić, że w czeskich i polskich przekładach zostały wykorzystane następujące gatunki ptactwa:

Zest. 1 - Księga Izajasza 38,14 - przetlumaczone ptasie ekwiwalenty

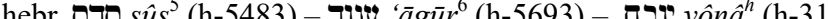

BK 1613/2009

BO 1417/2009

reřáb ${ }^{7}$ - vlaštovice - holubice

ptáče vlastovičie - holubicé

(żuraw - jaskółka - gołębica)

ČEP 2008

rorejs - jeřáb-holubice

ČSP 2009

rorejs - jeřáb-holubice

B21 2009

drozd-rorejs - holubice

PN

rorýs - bulbul - holubice

JB 2009

vlaštovka-holubice (młode jaskółczę - gołębica)

$\rightarrow \quad$ [brak żurawia

(jerzyk - żuraw - gołębica)

(jerzyk - żuraw - gołębica)

(drozd - jerzyk - gołębica)

$\rightarrow \quad$ [brak żurawia

(jerzyk - bilbil - gołębica)

$\rightarrow \quad$ [brak żurawia

(jaskółka - gołębica)

[brak żurawia]

dze Kapłańskiej (Kpł 11,13-19; Pwt 14,11-20), czyli tzw. katalogu zwierzą „czystych i nieczystych”, w której przethumaczone nazwy ptaków nie są pełnymi odpowiednikami. Warto również zauważyć, że w Piśmie Świętym w wyżej wymienionych przykładach zastosowano klasyfikację popularną, a nie naukową ptaków, o czym świadczyć może np. nietoperz (Kpł 11,19, Pwt 14,18), który, jak wiemy, nie jest ptakiem, ale jest ssakiem.

${ }^{5}$ Jak zaznacza czeski Biblický slovnik, analizując przede wszystkim leksykę z Biblii Kralickiej (BK 1613) ,překlad hebr. sûs je nejistý” (Novotný 1992, s. 830)tłumaczenie wyrazu hebr. sûs jest niepewne, co może mieć przełożenie na staropolski przekład Biblii Gdańskiej (BG 1632).

${ }^{6}$ Podreczny stownik hebrajsko-polski Starego Testamentu thumaczy hebr. wyraz עיפוך 'āgūr jako 'gatunek ptaka', wyszczególniając dwóch konkretnych przedstawicieli awifauny, czyli jaskółkę oraz drozda, ale stawiając przy nich znak zapytania (Briks 2000, s. 251), co wskazuje na niełatwa identyfikacje tego gatunku.

${ }^{7}$ Pozostawiam oryginalną pisownię řeř́áb, jaka znajduje się na kartach Biblii Kralickiej (tłum. BK 1613/2009, s. 602). Jest to staroczeska forma, por. również wyrażenia řežáb i žeřav (Holub, Kopečný 1952, s. 322) oraz žeřáb i žeřáv (ESJČ 
BJW 1599/2000 młode jaskótcze-gotębica

NBG

BT 1989

BWP 1997

BW 2001

BP 2012

jaskótka-gotębica

piskle jaskótcze - gotębica

jaskótka-gotębica

PN 2012

piskle jaskółcze-gołab

jaskótka-gotab

jerzyk-bilbil-gotab

Tylko w dwóch, będących jednymi z najstarszych analizowanych tłumaczeń Pisma Świętego i pochodzących z początku XVII wieku, czyli czeskiej Biblii Kralickiej (1613) oraz polskiej Biblii Gdańskiej (1632), zachowano identyczny dobór słownictwa oraz - co jest bardzo ważne - zachowano także jednakową kolejność ptasich ekwiwalen-

1997, s. 222), które w późniejszym okresie dzięki głosce [j] przekształciły się w formę jeřáb ‘żuraw'. W językach słowiańskich obserwujemy zjawisko występowania $\check{z} \mathrm{w}$ nagłosie tego leksemu, por. słowacki žeriav, pol. żuraw, ros. žurávl, ser./chor. žerav, wywodzące się ze starosłowiańskiego žeravb (ČES Rejzek 2001, s. 248), por. zjawiska asymilacji i desymilacji (Machek 1997, s. 222). Znane były także staroczeskie wyrażenia: jerzab (znajdujące się w encyklopedii Pavla Žídka: Liber viginti arcium - czes. Kniha dvacatera umění - hasło nr 22), rzerzab, stosowane przez Claretusa w jego pracach (Physiologiarius, czes. Fyziologár̆; Glossarius, czes. Glosář i Bohemarius, czes. Bohemáŕ; por. Hadravová 2008), oraz řeráb (Komárek 2007, s. 80). Staročeský slovník podkreśla możliwość starosłowiańskich oboczności jarębr/jerębъ oraz zmianę głoskową stsł. žeravb na řeřáb /žeŕáb (Gebauer 1970, s. 632).

${ }^{8}$ Pozostawiam pierwotna, oryginalna pisownie w formie leksemu żóraw, jaka znajduje się na kartach Biblii Gdańskiej (BG s. 574). Dotyczy to również staropolskiej pisowni ó. Zóraw - jak podaje SEJP - oznacza 'krzyczeć' (Brückne 1927/1993, s. 666). Donośny, wibrujacy, głęboki i dźwięczny głos maja właśnie żurawie, zwany jest on klangorem, czes. troubivý hlas (jako jednostajny, powtarzający się wysoko w powietrzu dźwięk ptactwa - najczęściej żurawi), który powstaje dzięki specjalnej budowie tchawicy, bardzo wydłużonej, tworzącej pętle wewnątrz mostka (por. Szczepanowicz, Mrozek 2007, s. 152-153), dzięki czemu ptaki te sa słyszalne na znaczną odległość tów językowych, por. sekwencję jednostek leksykalnych: czes. řeřáb - vlaštovice - holubice $\rightarrow$ pol. żóraw -jaskótka - gołębica, czego już nie możemy powiedzieć o pozostałych przedstawianych wersjach translacyjnych. W Czeskim Przekładzie Ekumenicznym (ČEP 2008, s. 719) i Czeskim Przekładzie Studyjnym (ČSP 2009, s. 869) pojawia się czwarty przedstawiciel kategorii pojęciowej ptactwa-czes. rorejs (pol.jerzyk), który występuje na pierwszym miejscu, w konsekwencji czego analizowany żuraw automatycznie przesuwa się tym razem na drugie miejsce. Trzeba podkreślić, że jerzyki to ptaki, które są często mylone $\mathrm{z}$ jaskółkami (por. domenę/fasetę/wyidealizowane modele kognitywne wyglądu; Langacker 1987, 1995, Wierzbicka 1999, Lakoff 1987), z którymi jednak nie są w ogóle spokrewnione (por. Hampl 2013, s. 89). W czeskim Przekładzie Biblii XXI wieku (B21 2009, s. 916) uwidacznia się piąty reprezentant ptaków - drozd, który występuje na pierwszym miejscu, a na drugim pojawia się czes. rorejs jako pol. jerzyk. W czeskim przekładzie PNS występuje szósty gatunek ptaka bulbul (pol. bilbil). W czeskojęzycznym współczesnym przekładzie Pisma Świętego - Slovo na cestu (SNC) została przez thumaczy wykorzystana siódma nazwa ptaka - czes. jestř́b. Zawsze na ostatnim, trzecim miejscu w tych sześciu analizowanych czeskich tłumaczeniach (BK, ČEP, ČSP, B21, PNS i SNC) i jednym polskim przekładzie (BG) znajduje się leksem holubice jako odpowiednik polskiej gołębicy, który również pojawia się w kolejnych tłumaczeniach (BO, JB, BJW, NBG, BT, BWP) i zajmuje w nich nie trzecie, ale drugie miejsce, przy czym i tu jest to miejsce ostatnie, ponieważ w wersecie tym występuje dwóch reprezentantów omawianej kategorii pojęciowej (por. pisklę/młode jaskółcze-gołębica). W trzech polskojęzycznych tłumaczeniach (BW, BP i PNŚ) możemy zaobserwować zamianę rodzaju gramatycznego, ponieważ zamiast gołębicy został wykorzystany gołą.

W czeskim przekładzie biblijnym Slovo na cestu (SNC 2011, s. 822) w analizowanym fragmencie Pisma Świętego (Iz 38,14) odnotowałem leksem jestř́b i uważam, że chodzi o „niekonsekwencję" lub o „niezamierzoną” pomyłkę w tłumaczeniu, a ściślej o literówkę 
-st, tzw. czeski błąd, gdyż w języku czeskim słowo jeřáb oznacza 'żurawia', a jestráb 'jastrzębia'. Mamy do czynienia z dużą zbieżnością fonetyczną, w wyniku której jednak powstaje obraz zupełnie innych ptaków. Jak widać i na takie trudności muszą być thumacze uwrażliwieni i w dużej mierze wyczuleni. $Z$ taką sytuacją natomiast nie spotykamy się już w drugim analizowanym wersecie biblijnym (Jr 8,7patrz przykład II).

Należy podkreślić, że we wszystkich szesnastu przeanalizowanych przekładach biblijnych (Iz 38,14) nazwy przedstawicieli kategorii pojęciowej ptactwa występują w postaci form liczby pojedynczej.

Drugi przykład $(\mathrm{Jr} 8,7)$ poddano również szczegółowej analizie, ze względu na to, że występuje w nim interesujący mnie szczególnie reprezentant ptaków - żuraw. Bliski Wschód stanowił tunel powietrzny dla wszystkich ptaków wędrownych (śpiewających, wodno-lądowych i drapieżnych), które przelatywały przez Palestynę w drodze do Afry$\mathrm{ki}$ i z powrotem w trakcie jesienno-wiosennych migracji. Zachowanie niektórych ptaków zostało wykorzystane w Biblii do przekazania ważnej nauki moralnej. Potwierdzeniem tego jest omawiany fragment z proroczej Księgi Jeremiasza (Jr 8,7), w którym leksem żuraw jest bazą dla metafory odwzorowujacej przyrode i informujacej o tym, że instynkt przedstawicieli różnych gatunków ptaków (zwłaszcza ptaków wẹdrownych) jest niezawodny w przeciwieństwie do postawy religijnej i braku posłuszeństwa narodu Bożego. Porównajmy, jak te kwestie zostały przedstawione w czeskich i polskich przekładach biblijnych (patrz przykład nr II):

(II) BK Ješto čáp u povětří zná nařizené časy své, a hrdlička i řeřáb i vlaštovice šetř́ času př́letu svého, lid pak můj nezná soudu Hospodinova. (Proroctví Jeremiáše proroka 8,7) - (tłum. BK 2009, s. 630)

BO Luňák na nebi poznal [na nebi] svój čas. Hrdlicě a vlastovicě a čapek střěhli sú času př́štie svého, ale lid mój nepoznal jest súdu božieho. (Jeremiáš 8,7) - (tłum. BO 2009, s. 197).

ČEP I čáp na nebi zná svůj čas, hrdlička, vlaštovka a jeřáb dodržují čas svého př́letu, ale můj lid nezná Hospodinovy řády (Jeremjáš 8,7) - (thum. ČEP 2008, s. 761).
ČSP I čáp na nebi zná svůj určený čas, hrdlička, vlaštovka i jeřáb zachovávají dobu svého př́iletu, ale můj lid nezná Hospodinovo nařízení. (Jeremjáš 8,7 ) - (tłum. ČSP 2009, s. 913)

B21 I ten čáp na nebi zná svá období, hrdlička, rorýs i drozd dodržují čas, kdy se mají stěhovat. Můj lid ale netuší, neví, co Hospodin nařídil. (Jeremiáš 8,7 ) (thum. B21 2009, s. 986).

PNS I čáp na nebesích - ten dobře zná své ustanovené časy; a hrdlička a rorýs a bulbul - každý dobře zachovává čas svého př́iletu. Ale pokud jde o můj lid, ten nepoznal Jehovi̊v soud. (Jr 8,7) - (tłum. http://www.jw.org/cs/publikace/bible-online)

JB I čáp na obloze zná svůj čas, hrdlička, vlaštovka i jeřáb zachovávají dobu svého tahu. Ale můj lid nezná Jahvovo právo! (Jeremiáś 8,7) - (thum. JB 2009, s. 1408)

SNC Dokonce i tažní ptáci jako jsou čápi, hrdličky, vlaštovky či jeřábi dobře vědí, kdy se mají vrátit, a každý rok ve stanovenou dobu přilétají. Avšak mému národu jsou má nařízení cizí. (Jr 8,7) - (SNC 2011, s. 894).

BG I bocian na powietrzu zna ustawione czasy swoje, i synogarlica, i żóraw, i jaskółka przestrzegają czasu przylecenia swego; ale lud mój nie zna sądu Pańskiego. (Proroctwo Jeremijaszowe 8,7) - (BG s. 601).

BJW Kania na powietrzu poznała czas swój, synogarlica i jaskółka, i bocian strzegły czasu przyszcia swego: a lud mój nie poznał sądu Pańskiego. (Proroctwo Jeremiaszowe 8,7) - (thum. BJW 2000, s. 1591).

NBG Nawet bocian w przestworzach zna swoje pory; także synogarlica, jaskółka i żuraw przestrzegają czasu swojego przylotu - lecz Mój lud nie zna sądu WIEKUISTEGO. (Jr 8,7) - (http://www.biblest.com.pl)

BT Nawet bocian w przestworzach zna swoja pore, synogarlica, jaskółka i żuraw zachowują czas swego przylotu. Naród mój jednak nie zna Prawa Pańskiego. (Księga Jeremiasza 8,7) - (tłum. BT 1989, s. 918).

BWP Nawet bocian w przestworzach czas swój rozpoznaje, podobnie synogarlica, jaskółka i żuraw - wszystkie przestrzegają czasu swej wędrówki. Mój zaś lud nie chce uznać praw swojego Pana. (BWP 1997, s. 1535).

BW Nawet bocian w przestworzach zna swój czas, synogarlica, jaskółka i żuraw przestrzegają pory swojego przylotu, lecz mój lud nie chce znać prawa Pana. (Księga Jeremiasza 8,7) - (tłum. BW 2001, s. 824).

BP Nawet bocian w przestworzach zna ustalone swe pory, synogarlica, jaskółka i żuraw przestrzegają czasu swego przylotu, ale lud mój nie zna Prawa Jahwe. (Księga Jeremiasza 8,7) - (tłum. BP 2012, s. 1128).

PNŚ Nawet bocian na niebiosach dobrze zna swe wyznaczone czasy; również turkawka i jerzyk, i bilbil starannie przestrzegają czasu swego przylotu. 
Lecz mój lud nie poznał sądu Jehowy (Księga Jeremiasza 8,7) - (tłum. PNŚ 1997, s. 978).

W każdym przedstawionym czeskim i polskim przekładzie w Księdze Jeremiasza $(\mathrm{Jr} 8,7)$ znajdują się nazwy c z t e r e c h reprezentantów kategorii pojęciowej ptactwa. Natomiast we wszystkich czeskich wersjach językowych odnotowałem łącznie aż o s i e m nazw gatunków ptaków: čáp, hrdlička, jeř́áb, vlaštovka, luňák, rorýs, drozd i bulbul. W wersjach polskojęzycznych w tym samym badanym wersecie biblijnym (Jr 8,7) występuje również o s i e m gatunków ptaków: bocian, synogarlica, żuraw, jaskółka, kania, jerzyk, turkawka i biblil. Na podstawie przeprowadzonej analizy porównawczej należy powiedzieć, że nie pojawia się jednak w polskich przekładach biblijnych drozd, odnotowano zaś jeszcze inny gatunek ptaka - turkawkę, czyli zespół tłumaczy dokonujący przekładów Pisma Świętego zastosował tu różnorodną ptasią ekwiwalencję językową. Możemy stwierdzić, że w pięciu polskojęzycznych przekładach: w Biblii Tysiąclecia (BT 1989, s. 918), Biblii Warszawskiej (BW 2001, s. 824), Biblii Poznańskiej (BP 2012, s. 1128), Biblii Warszawsko-Praskiej (BWP 1997, s. 1535) i Nowej Biblii Gdańskiej (NBG), oraz w czterech czeskojęzycznych tłumaczeniach: w Czeskim Przekładzie Ekumenicznym (ČEP 2008, s. 761), Českim studijním překladzie (ČSP 2009, s. 913), Jeruzalémskiej biblii (2009, s. 1408) i Slovie na cestu (SNC 2011, s. 894) jest zgodność nie tylko pod względem używanego nazewnictwa, ale także w zakresie kolejności wymienianych gatunków ptaków, por. sekwencję używanych jednostek leksykalnych: pol. bocian-synogarlica - jaskótka - zuraw $\rightarrow$ czes. čáp - hrdlička - vlaštovka - jeřáb ${ }^{9}$

${ }^{9} \mathrm{~W}$ przekładach biblijnych $\mathrm{w}$ wielu miejscach występują przypisy, których celem jest zwykle wyjaśnienie jakiegoś elementu językowego lub kulturowego, który thumacz traktuje jako potencjonalnie niezrozumiały dla czytelnika (por. Kizeweter 2009, s. 37). W przypisie czeskojęzycznego thumaczenia (ČSP 2009, s. 913) istnieje wzmianka o tym, że oprócz żurawia może chodzić także o innego ptaka drozda, czyli potwierdzałyby się przypuszczenia, że obecność opisywanej nazwy żuraw w tekstach biblijnych budzi wątpliwości, por. przekład pośredni - Septuaginte, która pomija ten termin (Szczepanowicz, Mrozek 2007, s. 152). Również Wulgata pomija wspominany leksem. czyli mamy tu do czynienia z i d e n t y c z n y m d o b o re m jednostek leksykalnych i z g o d n ą k o le j n o ś c i ą nazw ptaków. Jedyna różnica pomiędzy omawianymi dziewięcioma przekładami biblijnymi (ČEP, ČSP, JB, SNC, NBG, BT, BWP, BW i BP) polega na tym, że W czeskim współczesnym tłumaczeniu biblijnym Slovo na cestu (SNC 2011, s. 894) została użyta liczba mnoga, por. čápi - hrdličkyvlaštovky - jeřábi (pol. bociany - synogarlice - jaskótki-żurawie), a w pozostałych tłumaczeniach wszędzie została użyta liczba pojedyncza (por. poniższe zestawienie):

Zest. 2 - Ksiega Jeremiasza 8,7 - przetlumaczone ptasie ekwiwalenty

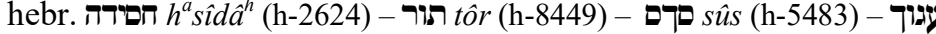
'àgūr (h-5693)

BK 1613/2009 čáp-hrdlička-řreŕáb-vlaštovice （bocian-synogarlica-żuraw-jaskółka)

BO 1417/2009 Luňák-Hrdlicě-vlastovicě - čapek (kania-synogarlica-jaskółka-bocian) $\quad \rightarrow \quad$ [brak żurawia]

ČEP $2008 \quad$ čáp-hrdlička-vlaštovka-jeřáb $\quad \begin{aligned} & \rightarrow \\ & \text { (bocian-synogarlica-ja- }\end{aligned}$

ČSP $2009 \quad$ čáp -hrdlička-vlaštovka - jeřáb (bocian-synogarlica-jacáp-hrdlička-vlaštovka-jeráb (bocian-synogarlica-ja-
skółka-żuraw) čáp - hrdlička - rorýs - drozd rzyk-drozd)

B21 2009

PNS čáp - hrdlička - rorýs - bulbul -jerzyk-bilbil)

JB 2009 čáp - hrdlička - vlaštovka - jeřáb skółka-żuraw)

SNC 2011 čápi - hrdličky - vlaštovky - jeřábi skółki-żurawie)

ocian-synogarlica-je-

$\rightarrow \quad$ [brak żurawia] (bocian-synogarlica$\rightarrow \quad$ [brak żurawia] (bocian-synogarlica-ja-

(bociany-synogarlice-ja-

BG 1632/1964 bocian-synogarlica - źóraw-jaskótka BJW 1599/2000 Kania-synogarlica - jaskótka - bocian NBG bocian-synogarlica-jaskótka-żuraw BT 1989 bocian-synogarlica-jaskótka-żuraw BWP 1997 bocian-synogarlica-jaskótka-żuraw BW 2001 bocian-synogarlica-jaskółka-żuraw BP 2012 bocian-synogarlica-jaskótka-żuraw PNŚ 1997 bocian-turkawka-jerzyk-bilbil $\rightarrow \quad[$ brak żurawia $]$ 
Z analogiczną sytuacją - zachowaną identyczną kolejnością przytaczanych nazw ptaków - spotykamy się w tłumaczeniu czeskiej $B i$ blii Kralickiej (BK 2009, s. 630) i polskiej Biblii Gdańskiej (BG s. 601): pol. bocian - synogarlica - zuraw - jaskółka $\rightarrow$ czes. čáp hrdlička - ř ř́áb - vlaštovice. Po przeprowadzonej szczegółowej analizie leksykalnej, podczas której porównaliśmy oddzielnie czeskie przekłady i oddzielnie polskie przekłady biblijne, zauważyliśmy również rozbieżności $\mathrm{w}$ grupie czeskich przekładów pomiędzy BK i $\breve{C} E P+\check{C} S P+J B+S N C$, a także $w$ grupie polskich przekładów między tłumaczenami BG i NBG+BT+BWP+BW+BP, które polegają na tym, że ostatnie dwie nazwy ptaków zmieniają kolejność, czyli raz analizowany żuraw jest na przedostatnim, tr z e c i m miejscu: bocian -synogarlica - ̇uraw - jaskótka (czes. čáp - hrdlička - jeřáb - vlaštov$k a$ ), a następnym razem zmienia swoje miejsce: bocian - synogarlica -jaskótka-juraw (czes. čáp-hrdlička-vlaštovka-jeřáb) i znajduje się na ostatnim, c z w a r t y m miejscu. W czeskim przekładzie Biblii XXI wieku (B21) na przedostatnim i ostatnim (trzecim i czwartym) miejscu pojawia się zaś: rorýs - drozd. Natomiast w czeskojęzycznej Olomouckiej biblii (BO) i polskojęzycznej Biblii Jakuba Wujka (BJW) pojawia się nowy gatunek ptaka: czes. luňák-pol. kania, który występuje na pierwszym miejscu. Ta zbieżność translatologiczna polega na tym, że oba przekłady niewątpliwie wzorowały się bezpośrednio na łacińskiej Wulgacie ${ }^{10}$. W polskim wydaniu Biblii w przekładzie Jakuba Wujka z 1599 roku (BJW) i czeskim wydaniu Biblii Otomunieckiej z 1417 roku (BO) nie została wykorzystana nazwa żuraw, natomiast zamiast niego występuje bocian i znajduje się na ostatnim, czwartym

${ }^{10} \mathrm{~W}$ celu łatwiejszej orientacji w wywodzie o wpływie przekładów pośrednich, jakim jest Wulgata, przytaczam laciński tekst sporządzony przez świętego Hieronima: milvus in caelo cognovit tempus suum turtur et hirundo et ciconia custodierunt tempus adventus sui populus autem meus non cognovit iudicium Domini. Tekst ten wskazuje na to, jak czeska Biblia Otomuniecka (BO) i polska Biblia Jakuba Wujka (BJW) wzorowały się na Wulgacie, zwłaszcza w zakresie tłumaczenia nazw ptaków, por. wyrazy wytłuszczone oraz zastosowana ich kolejność w omawianym wersecie. miejscu, a w pozostałych czternastu analizowanych thumaczeniach (BK, CEP, ČSP, B21, PNS, JB, SNC, BG, NBG, BT, BWP, BW, BP i PNŚ) wspomniany bocian (czes. čáp) jest zawsze wymieniany na początku, czyli na pierwszej pozycji, rozpoczynającej wyliczanie ptaków w tym wersecie. Nowy gatunek ptaka pojawia się również w jednym czeskim i polskim tłumaczeniu biblijnym: PNS i PNŚ. Chodzi o bilbila (pol. bulbul), który znajduje się na ostatnim, czwartym miejscu. Spośród przeanalizowanych szesnastu wersji językowych (ośmiu czeskich i ośmiu polskich) żuraw (czes. jeř́a) nie został uwzględniony w pięciu przekładach biblijnych - trzech czeskich (BO, B21 i PNS) oraz dwóch polskich (BJW i PNŚ).

Zauważyłem również, że we wszystkich ośmiu czeskich oraz ośmiu polskich analizowanych tłumaczeniach, mimo że nie jest zachowana kolejność nazw gatunkowych, to jednak zachowana jest ich ekwiwalencja językowa w postaci hiponimicznych leksemów jako je d n o s tek n i ż z z g o r z ę d u: pol. bocian, synogarlica, żuraw, jaskótka,jerzyk, drozd, kania i bilbil - czes. čáp, hrdlička, jeřáb, vlaštovka, rorýs, drozd, luňák i bulbul, czyli nie pojawia się hiperonim ptak, jak to ma miejsce w niektórych innych wersetach biblijnych (por. Kp1 14,$4 ; 5 ; 6 ; 7 ; 49 ; 50 ; 51 ; 52 ; 53 ;$ Hi 40,29[24]; Ps 102,8; 104,17; Prz 7,$23 ; 26,2$ ), w których występują oboczności wróbel - ptak (por. Hampl 2011, s. 241-255), gdzie wyraz ptak jest postrzegany jako jed no stka wy ż z e g o rz ędu. Nie spotykaliśmy się również podczas przeprowadzonej analizy dotyczącej Księgi Jeremiasza (Jr 8,7) z sytuacją, w której by występowało binominalne tzw. dwuczłonowe/dwuimienne nazewnictwo, jakie czasami pojawia się $\mathrm{w}$ niektórych przekładach biblijnych, np. kania ruda, kania czarna, orzeł morski, sęp kasztanowaty, sęp czarny, sęp górski, sęp biały, sowa uszata itd.

Eksperci biblijni uważają (Douglas 1996, s. 1163; Novotný 1992, s. 1217; Ryken, Wilhoit, Longman 1998, s. 846; Bowker 2005, s. 267), że znajdujące się w niniejszych dwóch analizowanych wersetach (Iz 38,14 i Jr 8,7) hebrajskie słowo 'âgûr [מפוד [h-5693] powinno być thumaczone jako żuraw (czes. jeřáb), a hebr. sûs פ [h-5483] (biorąc 
pod uwagę sposób śpiewu) jako jaskótka (czes. vlaštovka), chociaż niektórzy badacze sądzą, że hebr. sûs może oznaczać jerzyka (Packer, Tenney 2007, s. 186), co potwierdzałyby także omawiane fragmenty tłumaczeń, gdzie zamiast jaskółki używane są ekwiwalenty w postaci jerzyków, a zamiast żurawi wymieniane są bilbile ${ }^{11}$.

W niniejszym artykule chciałem zwrócić uwagę na istotne czynniki, które powinny być uwzględniane w każdym procesie translacyjnym i przeprowadzanej krytycznej ocenie tekstu. Chodziło mi o to, aby uwaga tłumaczy była skoncentrowana na następujących zagadnieniach, wynikających z tzw. ,translatologicznego rachunku sumienia" (Lipiński 2006, s. 137-138). Przedmiotowe zagadnienia przedstawiam w zmodyfikowanej wersji, przystosowanej do potrzeb analizy niniejszych czeskich i polskich przekładów biblijnych. Godne zastanowienia są poniższe kwestie:

- czy i l o ść przetłumaczonych nazw zwierząt (w naszym przypadku ptaków) w każdym omawianym wersecie biblijnym jest we wszystkich czeskich i polskich wersjach językowych jednakowa,

- czy istnieją problemy z tłumaczeniem niektórych nazw zwierząt/ptaków,

${ }^{11}$ Bilbile (Pycnonotidae) należą do rodziny małych lub średniej wielkości ptaków wróblowatych, a w świetle najnowszych badań ornitologicznych najbardziej spokrewnione są z pokrzewkowatymi (Sylviidae), skowronkami (Alaudidae), jaskółkami (Hirundinidae) oraz nektarnikami (Nectariniidae) (por. Svensson 2012 s. 358), chociaż mylone są z drozdami. Występują na Bliskim Wschodzie, Półwyspie Arabskim i w Afryce. Żyją w gorących południowych biotopach i są towarzyskie, żwawe i głośne. Maja krótką szyje, krótkie skrzydła i długi ogon. W wielu przekładach biblijnych hebr. słowo עמוך 'a $\bar{a} \bar{u} r$ (h-5693) zostało przetłumaczone jako żuraw (BK, ČEP, ČSP, JB, SNC, BG, NBG, BT, BWP, BW, BP), lecz król Ezechiasz podaje, że ten ptak piszczy, szczebiocze, kwili, czego nie można odnieść do głębokiego, wibrującego i przenikliwego klangoru (klangorowego dźwięku), tubalnego trąbienia żurawia. Dlatego niektórzy tłumacze (PNS, PNŚ) zastosowal inny leksem bilbil (czes. bulbul), którego głos jest fletowy (w odróżnieniu od trabiącego, przenikliwego i buczaco-wyjącego głosu żurawia). Wydawane dźwięki bilbilów opisywane sa jako kombinacja piszczenia z ćwierkaniem oraz szczebiotania $\mathrm{z}$ świergotaniem.
- czy we wszystkich analizowanych tłumaczeniach biblijnych została zachowana taka sama k o lej n o śc przytaczania nazw zwierząt/ /ptaków,

- czy w czeskich i polskich przekładach biblijnych zostały wymienione jednakowe zwierzęta (ten sam gatunek, rodzaj, rodzina, rząd, gromada, typ itd.), czy zachowana jest w ła ś c i wa tak s o n om i a zoologiczna

- czy w analizowanych czeskich i polskich tłumaczeniach pojawiaja się s y n o n i m i c zn e, czyli pod względem semantyki bliskoznaczne określenia zwierzęce,

- czy w przekładach jest zachowana k a t e g o r y z a c j a, czyli czy są stosowane odpowiednio nadrzędne i podrzędne wyrażenie leksykalne (hiponimy i hiperonimy względnie kohiponi$\mathrm{m} y)$,

- czy nazewnictwo różnorodnych przedstawicieli kategorii pojęciowej ptactwa reprezentujące dany rodzaj powiązań semantycznych zostało uhierarchizowane pod wzgledem stopnia „o gól no ś c i” i ,ko n kret no ści”,

- czy w procesie thumaczenia uwzględniono hierarchizację elementów komunikatu (na wszystkich poziomach), odnoszących się do subiektywnej oceny dokonującego przekładu,

- czy pojawiają się wariancje w kategoryzacji „o g ó ł” - „s z c z e gó 1", dotyczące wyekscerpowanych hiponimicznych lub hiperonimiczny ch leksemów,

- czy proces tłumaczenia czeskich i polskich jednostek leksykalnych dotyczy swoistych przybliżeń aproksymacyjnych i formalno-estetycznej rekonstrukcji ,ptasiej ekwiwalencji" w tekstach języka docelowego,

- czy jest zachowany (naturalny) rodzaj bi ol og i c zn y i gra $\mathrm{m}$ a t y c z n y analizowanych nazw zwierząt, tłumaczonych na kartach Biblii,

- czy w badanych czeskich i polskich przekładach została zachowana ta sama 1 i c z b a (pojedyncza bądź mnoga), 
- czy w niektórych fragmentach nie mamy do czynienia z $\mathrm{k} \mathrm{a} 1 \mathrm{k} \mathrm{a} \mathrm{m} \mathrm{i}$ języ kow y mi,

- czy w niektórych analizowanych fragmentach Pisma Świętego zdarzają się o puszczenia, zwłaszcza nazw ptaków,

- czy porównując czeskie i polskie przekłady biblijne spotykamy się z tzw. zerową ekwiwalencją bądź leksyką bezekwiwalentna,

- czy częściej w przekładach występuje jednoczłonowe lub dwuczłonowe/dwuimienne tzw. bi n o minalne nazewnictwo,

- czy in now a c j e j ę z y k o w e poszerzają zasób leksykalny każdego języka i wpływają na obrazowe urozmaicenie tekstu,

- czy w analizowanych przekładach biblijnych (nawet w tej samej edycji) zdarzają się różnorodne $\mathrm{zap}$ is y $\mathrm{graficz}$ e przedstawicieli kategorii pojęciowej ptactwa,

- czy mamy do czynienia z ujednoliceniem przekładu pod względem doboru słownictwa $\mathrm{z}$ zakresu tzw. harmonizacji leksy$\mathrm{kalnej}$ polegającej na redukowaniu liczby wykorzystywanych dubletów leksykalnych,

- czy przekłady pośrednie (gr. Septuaginta i łac. Wulgata) miały wpływ na thumaczenie w językach narodowych,

- czy niektóre thumaczenia są do siebie bardzo zbliżone (mają wspólną leksykę) oraz czy niektóre czeskie i polskie przekłady zdecydowanie się od siebie r ó ż n i ą i używają odrębnej terminologii.

Odpowiedzi na wszystkie wyżej postawione pytania znajdują się w tabeli $\mathrm{nr} 1$.

Frekwencja analizowanego leksemu żuraw (czes. jeřáb) występującego w szesnastu przebadanych przekładach biblijnych (8 czeskich i 8 polskich) przedstawia się następująco:

- dwa razy w BK, ČEP, ČSP, BG;

- jeden raz w JB, SNC, NBG, BT, BWP, BW, BP;

- zero razy w BO, B21, PNS, BJW, PNŚ.
Tabela 1. Najważniejsze różnice translacyjne na przykładzie biblijnego reprezentanta awifauny - żurawia

\begin{tabular}{|c|c|c|}
\hline \multirow[b]{2}{*}{ Rodzaj tlumaczenia } & \multicolumn{2}{|c|}{$\begin{array}{l}\text { Wykorzystana zwierzęca (ptasia) leksyka } \\
\text { dotycząca żurawia, czes. jeř́ába }\end{array}$} \\
\hline & $\begin{array}{l}\text { Iz 38,14 } \\
\text { miejsce w wersecie } \\
\text { (1) (2) (3) }\end{array}$ & $\begin{array}{c}\text { Jr 8,7 } \\
\text { miejsce w wersecie } \\
\text { (1) (2) (3) (4) }\end{array}$ \\
\hline BK (Kralická bible) & řeřáb (1) & řeřáb (3) \\
\hline BO (Olomoucká bible) & $\begin{array}{l}\text { ptáče vlastovičie (1), } \\
\text { holubicě (2) }\end{array}$ & čapek (4) \\
\hline ČEP (Český ekumenický překlad) & jeřáb (2) & jeř́áb (4) \\
\hline ČSP (Český studijní překlad) & jeřáb (2) & jeř́áb (4) \\
\hline B21 (Bible překlad 21. století) & $\begin{array}{l}\text { drozd (1), rorejs (2), } \\
\text { holubice (3) }\end{array}$ & drozd (4) \\
\hline PNS (Překlad nového světa) & $\begin{array}{l}\text { rorýs (1), bulbul (2), } \\
\text { holubice (3) }\end{array}$ & bulbul (4) \\
\hline JB (Jeruzalémská bible) & vlaštovka (1), holubice (2) & jeř́áb (4) \\
\hline SNC (Slovo na cestu) & $\begin{array}{l}\text { rorýs (1), jestř́áb (2), } \\
\text { holubice (3) }\end{array}$ & jeřábi (4) \\
\hline BG (Biblia Gdańska) & żóraw (1) & żóraw (3) \\
\hline BJW (Biblia Jakuba Wujka) & $\begin{array}{l}\text { młode jaskółczę (1) gołębi- } \\
\text { ca (2) }\end{array}$ & bocian (4) \\
\hline NBG (Nowa Biblia Gdańska) & jaskółka (1), gołębica (2) & $\dot{z} u r a w(4)$ \\
\hline BT (Biblia Tysiąclecia) & $\begin{array}{l}\text { piskle jaskółcze (1) gołębi- } \\
\text { ca (2) }\end{array}$ & żuraw (4) \\
\hline BWP (Biblia Warszawsko-Praska) & jaskółka (1), gołębica (2) & $\dot{z} u r a w(4)$ \\
\hline BW (Biblia Warszawska) & $\begin{array}{l}\text { pisklę jaskółcze (1) gołąb } \\
\text { (2) }\end{array}$ & $\dot{z} u r a w(4)$ \\
\hline BP (Biblia Poznańska) & jaskółka (1), gołąb (2) & $\dot{z} u r a w(4)$ \\
\hline PNŚ (Przekład Nowego Świata) & $\begin{array}{l}\text { jerzyk (1), bilbil (2), } \\
\text { gołąb (3) }\end{array}$ & bilbil (4) \\
\hline
\end{tabular}




\section{Podsumowanie}

Na zakończenie warto zwrócić uwagę jeszcze na utrwalony obraz żurawia (czes. jeřáb) i zakorzenioną symbolikę opisywanego reprezentanta kategorii pojęciowej ptactwa. Analizowany żuraw, podobnie jak bocian, symbolizuje wzniosłość, nieśmiertelność, szczęście, podróż, wędrówkę, taniec, wiosnę, poranek, deszcz, wyrocznię, wróżbę, pilność, czujność, bystrość, wścibstwo, ostrożność, długowieczność, żądzę, miłość, pobożność, miłosierdzie, wierność, czystość, dobrobyt, arystokratyzm, zarozumiałość, snobizm, skąpstwo, głupotę, niezgrabność, paplanie, trajkotanie, zdradę, dobroduszność, sprawiedliwość, lojalność, inteligencję, mądrość, alfabet i poezję (Kopaliński 2001, s. 515). Cykliczne powroty żurawi na wiosnę do miejsca lęgu symbolizowały odrodzenie i dlatego żurawie stały się w chrześcijaństwie symbolem zmartwychwstania (Szczepanowicz, Mrozek 2007, s. 154). Dla wielu różnorodnych kultur, począwszy od Japonii ${ }^{12}$ i Chin, a kończąc na cywilizacjach śródziemnomorskich, żuraw stanowił alegorię sprawiedliwości, długowieczności i troskliwej dobroci (Cirlot 2012, s. 459) oraz nieśmiertelności (Becker 2002, s. 106), a od czasów antycznych był symbolem czujności (czes. bdělost - łac. vigilantia; por. Royt, Šedinová 1998, s. 124). W średniowiecznej medycynie jaja żurawi służyły do sporządzania pigułek nieśmiertelności (Kobilelus 2002, s. 362). Już w czasach antycznych i średniowiecznych uważano żurawia za symbol wspominanej czujności (Forstner 1990, s. 251; por. bestiariusze i traktaty o symbolice zwierzęcej; Aviarium 2005, s. 138, rozdz. XLIV), ponieważ podczas nocnego odpoczynku jeden osobnik ze stada żurawi zawsze czuwa, trzymając w szponach podkurczonej nogi kamień. Jeżeliby żuraw zasnął, kamień wypadnie mu z łapy i obudzi go. Kamyk trzymany przez żurawia podczas nocnej straży w interpretacji chrześcijańskiej wskazuje na Chrystusa, a łapa to stan umysłu. Pisze o tym S. Kobielus:

12 Japończycy żurawia uważają za symbol szczęścia, który stał się także obok gałązki kwitnącej wiśni motywem dekoracyjnym sztuki japońskiej (por. Kruszona 2008, s. 77).
Kto czuwał nad sobą, ten miał w umyśle Chrystusa (Kobielus 2012, s. 163).

Z punktu widzenia chrześcijaństwa zaprezentowany żuraw „kromě bělosti symbolizuje loajalitu, dobrotu a pořádek v řeholním životě" (Cooperová 1999, s. 66). Arystoteles podziwiał żurawia za roztropność, a starożytni za wytrwałość podczas długich lotów. Jego charakterystyczne poruszanie się podczas tokowania i wykonywane ruchy określamy mianem taniec żurawia (czes. jeřábi tanec), który był w średniowiecznej Europie, zwłaszcza u Greków i Rzymian symbolem miłości i radości z życia (Becker 2002, s. 106). W mitologii greckiej Tezeusz wraz ze swymi towarzyszami, którzy uniknęli śmierci, wykonywał po powrocie na wyspę Delos taniec żurawia (gr. geranikos), naśladujący poruszanie się po skomplikowanych ścieżkach labiryntu, przy czym tancerz-przewodnik pociągał ich na stronę śmierci (w lewo) lub na stronę życia (na prawo). W Europie taniec ten przetrwał do XIX wieku i był wykorzystywany w rytuałach religijnych. Taniec żurawia wykonywano w niektórych kościołach podczas świąt Wielkanocnych.

\section{Źródła}

Bible, Český studijni překlad Bible. Stará a Nová smlouva přeložené z původních jazyků. Praha: Nakl. KMS, 2009, první souborné vydání.

Bible,Písmo svaté Starého a Nového zákona (včetně deuterokanonických knih). Český ekumenický preklad. Praha: Česká biblická společnost, 2008.

Bible, Překlad 21. století. Přeloženo z hebrejštiny, aramejštiny, řečtiny. Praha: Vyd. Babilon, 2009.

Bible Slovo na cestu. Praha: Nakl. Česká biblická společnost, první vydání, 2011.

Bible Svatá, Písmo svaté Starého a Nového zákona podle posledního vydáni Kralického z roku 1613. Praha: Česká biblická společnost, 2009.

Jeruzalémská Bible - Písmo svaté vydané jeruzalémskou biblickou školou Krystal OP, první české vydání. Praha: Karmelitánské nakladatelství, 2009.

Staročeská bible drážd'anská a olomoucká. Kritické vydání nejstaršího českého překladu bible ze 14. století. V/1 Izaiáš-Daniel. vydání první. Praha: Nakl. Academia AV ČR, 2009.

Biblia to jest Całe Pismo Święte Starego i Nowego Testamentu z hebrajskiego i greckiego języka na polski pilnie i wiernie przetłómaczona. Warszawa 1964. 
Biblia to jest Pismo Święte Starego i Nowego Testamentu. Nowy przekład z języków hebrajskiego i greckiego opracowany przez Komisję Przekładu Pisma Świętego. Warszawa: Towarzystwo Biblijne w Polsce, 2001.

Biblia w przekładzie ksiedza Jakuba Wujka z 1599 r. Transkrypcja typu „B” oryginalnego tekstu z XVI w. Prymasowska Seria Biblijna, wydanie piąte. Warszawa: Oficyna Wydawnicza Vocatio, 2000.

Pismo Święte Stary i Nowy Testament w przekładzie z języków oryginalnych opracował zespół pod red. ks. Michała Petera (ST) i ks. Mariana Wolniewicza (NT), wydanie pierwsze - dodruk. Poznań: Wydawnictwo Świety Wojciech, 2012.

Pismo Święte Starego i Nowego Testamentu w przekładzie z języków oryginalnych opracował Zespół biblistów polskich z inicjatywy Benedyktynów Tynieckich, wydanie czwarte. Poznań-Warszawa: Wydawnictwo Pallottinum, 1989.

Pismo Święte Starego i Nowego Testamentu »Biblia Warszawsko-Praska«. W przekładzie z języków oryginalnych opracował Kazimierz Romaniuk, Pierwszy Biskup Warszawsko-Praski. Warszawa: Towarzystwo biblijne w Polsce, 1997.

Pismo Święte w Przekładzie Nowego Świata. Przetłumaczono z New World Translation of Holy Sciptures z uwzględnieniem języków oryginału. Strażnica Towarzystwo biblijne i traktatowe, 1997.

\section{Literatura}

A c h t e m e i e r P.J., 2004, Encyklopedia biblijna. Prymasowska Seria Biblijna, wydanie trzecie poprawione. Warszawa: Oficyna Wydawnicza Vocatio.

B a lá k o v á D., 2007, Princíp ekvivalencie vo frazeológii, [w:] Frazeologickés stúdie V. Princípy lingvistickej analýzy vo frazeológii. Editori D. Baláková, P. Durčo, I vydanie. Ružomberok: Vydavatelství Katolícké univerzity, s. 27-42.

B e c k e r U., 2002, Slovník symboli̊. Z něm. přel. P. Patočka. Praha: Nakladatelství Portál.

B e d n a r c z y k A., 2008, W poszukiwaniu dominanty translatorskiej. Warszawa: Wydawnictwo Naukowe PWN.

B o w k e r J., 2005, Bible - ilustrovaný průvodce Starým a Novám zákonem. Přel. i odpovědný red. Michal Janata, české vydání první. Praha: Ottovo Nakladatelství.

B riks P., 2000, Podręczny słownik hebrajsko-polski i aramejsko-polski Starego Testamentu. Prymasowska Seria Biblijna, wydanie trzecie. Warszawa: Oficyna Wydawnicza Vocatio.

B rü ckner A., 1927/1993, Stownik etymologiczny języka polskiego. Warszawa: Wydawnictwo Wiedza Powszechna.

B r zo zow s k i J., 2011, Stanać po stronie tlumacza. Zarys poetyki opisowej prze$k ł a d u$. Kraków: Wydawnictwo Uniwersytetu Jagiellońskiego.

C ir l o t J.E., 2012, Słownik symboli. Przekład Kania I. Kraków: Znak.

C o o p e r o v á J.C., 1999, Ilustrovaná encyklopedie tradičnich symbolů. Přel. Allan Plzák, vydání první. Praha: Nakladatelství Mladá fronta.
D o u g la s J.D., 1996, Nový biblický slovnik, první vydání. Praha: Nakladatelství Návrat domů.

D u n a j B. (red.), 2001, Popularny stownikjęzyka polskiego. Warszawa: Wydawnictwo Wilga.

F ili p e c J., D a n e š F., M e j s trú ík V. (red.) 2005, Slovník spisovné češtiny pro školu a veřejnost, vydání 4. Praha: Nakladatelství Academia.

F o r s tn e r D., 1990, Świat symboliki chrześcijańskiej. Przeł. Zakrzewska Wanda, Pachciarek Paweł, Tyrzyński Ryszard. Warszawa: Instytut Wydawniczy Pax.

G e b a u e r J., 1970, Slovník staročeský. Díl I [ $A-J$, druhé nezměněné vydání. Praha: Academia, Nakladatelství Československé akademie věd.

G r y g o v á B., 2010, Překlad odborného textu, [w:] Překlad a překládání. Olomouc Vydavatelství Univerzita Palackého, s. 203-214.

H a dravová A., 2008, Kniha dvacatera uméní mistra Pavla Židka část prírodovědná, vydání první. Praha: Nakladatelství Academia.

H a m p 1 L., 2011, Najistotniejsze podobieństwa i różnice przettumaczonych hiperonimicznych i hiponimicznych wyrazów leksykalnych $w$ przektadach czeskich i polskich wersetów biblijnych na wybranym przykladzie »ptak-wróbel«, Studia Slavica" XV, s. 241-255.

H a m $p 1$ L., 2013, Świat awifauny w polskich i czeskich przekładach Pisma Świętego (sowy i jaskótki). Bielsko-Biała: Wydawnictwo Naukowe ATH.

H e j w o w s k i K., 2006, Kognitywno-komunikacyjna teoria przektadu. Warszawa: Wydawnictwo Naukowe PWN

Holub J., Ko pe čný F., 1952, Etymologický slovnik jazyka českého. Praha: Státní nakladatelství učebnic v Praze.

$\mathrm{Http}$ //www.biblest.com.pl.

Http://biblia.apologetyka.com

Http://www.jw.org/cs/publikace/bible-online.

K e $m$ p f Z., 1984, Gotebica czy gołab?, ,Język Polski” LXIV, z. 5, s. 335-341.

$\mathrm{K}$ i z e w e te r M., 2009, Przepis na przypis - o przypisach na podstawie wybranych przektadów anglojęzycznej literatury pięknej na język polski, [w:] Jakość i ocena thumaczenia, red. A. Kopczyński, M. Kizeweter. Warszawa: Wydawnictwo SWPS Academica.

K o b i e l u s S., 2002, Bestiarium chrześcijańskie. Zwierzęta w symbolice i interpretacji. Starożytność i średniowiecze. Warszawa: Instytut Wydawniczy Pax.

Ko b i elu s S., 2005, Fizjologia i Aviarium. Średniowieczne traktaty o symbolice zwierzat. Kraków: Tyniec Wydawnictwo Benedyktynów.

K o b i e l u s S., 2012, Lapidarium christianum. Symbolika drogich kamieni. Wczesne chrześcijaństwo i średniowiecze, wydanie I. Tyniec: Wydawnictwo Benedyktynów.

Ko má r e k St., 2007, Ptáci v Čechách v letech 1360-1890 aneb tajemství rytiře von Sacher-Masocha, vydání I. Praha: Nakladatelství Academia.

K o p a 1 i ń s k i W., 2001, Stownik symboli. Warszawa. 
K o s s ow sk a M., 1968, Biblia w języku polskim. Poznań: Księgarnia św. Wojciecha.

K r u s z o n a M., 2008, Kulturalny atlas ptaków. Poznań: Zysk i S-ka Wydawnictwo. K u f n e r o vá Z., 2009, Čtení a překládání. Jinočany: Nakladatelství H\&H.

K w i le c k a I., 2003, Studia nad staropolskimi przekładami Biblii. Poznań: Uniwersytet im Adama Mickiewicza, Wydział Teologiczny, Instytut Slawistyki PAN.

K y a s V., 1997, Česká bible v dějinách národního písemnictví. Praha: Nakladatelství Vyšehrad.

L a k off G., 1987, Women, Fire and Dangerous Things. Chicago.

L a k off G., J o hn s on M., 1988, Metafory w naszym życiu. Warszawa.

L a n g a k e r R., 1987, Foundations of Cognitive Grammar, vol. I. Stanford.

L a n g c k e r R., 1995, Wyklady z gramatyki kognitywnej, Kazimierz nad Wista grudzień 1993. Lublin.

L a n g a c k e r R., 2003, Model dynamiczny oparty na uzusie językowym, [w:] Akwizycja języka w świetle językoznawstwa kognitywnego, red. E. Dąbrowska, W. Kubiński. Kraków, s. 30-117.

L i p i ń s k i K., 2004, Mity przektadoznawstwa. Kraków: Wydawnictwo Egis.

L i p ińs k i K., 2006, Vademecum tlumacza. Kraków: Wydawnictwo Idea.

M a che k V., 1997, Etymologický slovník języka českého. Praha: Nakladatelství Lidové noviny.

Majkiewicz A., 2008, Intertekstualność - implikacje dla teorii przektadu. Wczesna proza Elfriede Jelinek. Warszawa: Wydawnictwo Naukowe PWN.

Novotný A,. 1992, Biblický slovnik R-Ž. Praha.

P a c k e r J.I., T e n n y M.C., 2007, Stownik tla Biblii. Prymasowska Seria Biblijna. Warszawa: Oficyna Wydawnicza Vocatio.

R e j z e k J., 2001, Český etymologický slovnik. Voznice: Nakladatelství Leda.

R o y t J., Š e d i n o vá H., 1998, Slovník symbolủ kosmos, príroda a člověk v křest'anské ikonografii. Praha: Nakladatelství Mladá fronta.

Ryk e n L., W il ho it J.C., L o n g m an T., 1998, Stownik symboliki biblijnej. Obrazy, symbole, motywy, metafory, figury stylistyczne i gatunki litereckie w Piśmie Świętym. Prymasowska Seria Biblijna. Warszawa: Oficyna Wydawnicza Vocatio.

S t ě p a n o v a L.. 2009, Frazémy biblického původu (na materiále slovenštiny, češtiny a ruštiny), [w:] Aspekty literárnovedné a jazykovedné II. Editorky V. Kováčová, D. Baláková, J. Šindelářová. Ružomberok: Vydavatelství Katolické univerzity, s. 107-119.

Svensson L., 2012, Przewodnik Collinsa PTAKI. Najpetniejszy przewodnik do rozpoznawania ptaków Europy i obszaru śródziemnomorskiego. Tłum. $\mathrm{i}$ adaptacja Dariusz Graszka-Petrykowski. Warszawa: Multico Oficyna Wydawnicza.
Szczepanowicz B, Mrozek A., 2007, Atlas zwierzat biblijnych. Miejsce $w$ Biblii i symbolika. Kraków: Wydawnictwo WAM.

T a b a k o w s k a E., 2001, Językoznawstwo kognitywne a poetyka przekładu. Przeł. A. Pokojska. Kraków: Wydawnictwo TAiWPN Universitas.

T a b a k ow sk a E., 2008, O przekładzie na przykładzie. Kraków: Znak.

T a b a k ow s k a E., 2009, Ttumaczac się z tlumaczenia. Kraków: Znak

Ta ylor J.R., 2001, Kategoryzacja $w$ języku, prototypy $w$ teorii językoznawczej. Przeł. Anna Skucińska. Kraków: Wydawnictwo TAiWPN Universitas.

Ta ylor J.R., 2007, Gramatyka kognitywna. Przekład M. Buchta i Ł. Wiraszka. Kraków: Wydawnictwo TAiWPN Universitas.

V o ndráč e k M., 2008, Kognitivní aspekt gramatické kategorie jmenného rodu a životnosti, [w:] Clověk - jazyk - text. Sbornik z mezinárodni lingvistické konference konané u přiležitosti životního jubilea prof. PhDr. Jana Kořenského, DrSc. České Budějovice 18.-22. záři 2007. České Budějovice: FF Jihočeské univerzity, s. 51-54

Výklady IV ke Starému zákonu. Kniky prorocké, Izajášs, Jeremjáš, Pláč, Ezechiel, Daniel, Ozeás, Jóel Amos, Abdijašs, Jonášs, Micheás, Nahum, Abakuk, Sofonjáš, Ageus, Zacharjáš, Malachiáš, 1998. Vydř́: Karmelitánské nakladatelství Kostelní.

W i e r z b i c k a A., 1999, Język-Umyst-Kultura. Warszawa.

Z e hn a l o v á J., 2010, Překlad a hodnocení jeho kvality, [w:] Překlad a překládání. Olomouc: Vydavatelství Univerzity Palackého, s. 220-272. 